\title{
Implementation of Cooperative Learning Inside- Outside Circle Model to Improve Elementary School Students' Motivation and Learning Outcome
}

\author{
Tika Puji Hartini, Rusijono, \& Nasution \\ Universitas Negeri Surabaya \\ Surabaya, Indonesia \\ tika.85ph@gmail.com
}

\begin{abstract}
The aim of this research was to improve the fifthgrade students' motivation and learning outcomes on communication skills and cognitive aspect in SDN Ngagelrejo II Surabaya. This research used Classroom Action Research (CAR) and applied inside-outside circle which is one of cooperative learning models. The research was done with two cycles each of which consisted of planning, implementing, observing and reflecting. Questionnaires, observation, and tests were used to collect data. Data analysis technique used was descriptive quantitative analysis. The research result showed that students' motivation, communication skills, and cognitive aspect improved in each cycle. During the lessons, the students are well motivated, listen and understand the discussion.
\end{abstract}

Keywords- cooperative learning, inside-outside circle, motivation

\section{INTRODUCTION}

Education is a conscious and planned effort to create an atmosphere of learning and learning process so that learners actively develop their potential to have spiritual strength, selfcontrol, personality, intelligence, noble character, and skills needed (Education System of Indonesia). In modern life with fast communication, relationships become more intensive, and events become more complex. The introduction of students through the vehicle outside the school is still general and vague. For the introduction to be more meaningful, then the information that is still general and vague need to be systematized. Thus, schools have important roles and positions because what has been obtained outside school is developed and integrated into something more meaningful in school according to the level of student development and maturity. The subjects of social sciences aims to enable learners to have the ability to recognize concepts, have basic skills for logical and critical thinking, curiosity, inquiry, problem solving, and skills in social life, and awareness of social values, and have the ability to communicate, work together and compete in diverse societies, locally, nationally and globally.

From students' interview result about Social learning, most students did not really understand Social's content about life's changing and sustainability, the growth of nationalism and culture, education, economic and social culture of people in the time of colonization which have been learned. Students felt bored and saturated during the class. Most of the material were memorization that made the students found it difficult to understand all the material. Meanwhile, from interview result with the teacher, it is known that $60 \%$ of the students got under minimum score. Most of them got 68 while the minimum score was 75. Students' activities in communicating were rarely seen. Most students were silent, inactive and just received information from the teacher. Therefore, teachers should possess skills so they can make learning process more exciting, fun, and motivate students during the learning process. One way to address low motivation and low learning outcome especially communicative skills and cognitive aspect are by using cooperative learning Inside Outside Circle (IOC) model.

Based on that background, the aim of this research was to improve elementary school students' motivation and learning outcome by implementing Cooperative Learning model IOC type in Social Learning. According to [1], one advantage of Cooperative Learning IOC type is students have more chances to process information and develop communicative skills. By using Cooperative Learning IOC type in social learning, students can participate actively during the learning process and develop their potential. Besides, Cooperative IOC type learning model can facilitate teacher to deliver well-organized and directed material, so learning goals can be established effectively and efficiently [2].

According to some scientists [1, 3, 4] steps of Cooperative Learning IOC type learning model are as follows; introduction: the teacher does apperception, explains Cooperative Learning model IOC type, and delivers learning goals. Core step: the teacher divides students into groups, each group has to look for information based on tasks division given by the teacher, each group study independently, looks for information based on given tasks. Then, students gather, freely, not necessarily with the groups. Students are divided into 2 groups, inner circle, and outer circle. Inner circle students stand in circle facing outward and outer circle stands facing inward. So, members of inner and outer circle face each other and in pairs. Two students from each pair exchange information and can be done by all pairs at the same time. Then, students from inner circle should stay and students from outer circle will move one or two steps following clockwise. The movement will stop when students meet their first pairs. Results obtained should be discussed among the groups. Last step: the teacher gives feedback and evaluates discussed 
material. With the teacher's guidance, students make conclusion and the teacher gives evaluation and exercises.

Motivation has a very important role in students' success. According to [5] scientists have developed students' learning motivation indicator, namely learn persistently, solve problems tenaciously, study attentively, gain good learning outcome, and learn independently.

Learning outcome is students' achievement which is reached by students during teaching and learning process while carrying changes and behavior establishment. According to [6], learning outcome is action patterns, value, attitude explanation, appreciation, and skills. Learning outcome in this research is students' communicative skills and cognitive aspect.

[7] compared different definitions and communication theories. It can be known that the following factors were important to communicate orally [8]: words, emitter, acceptor, codes, signs, oral channels (oral message, oral discussion, dialog, etc), connotation (words and meaning in certain context), feedback, perception, production, meaning, culture, and reference. Idris suggested that communication as nonverbal skills gave feedback, presented ideas orally and written, did presentation and negotiation to achieve one goal and get support/agreement. Based on the explanation, effective learning and some communicative aspects should be developed according to those experts. The researcher developed communication skills on Social learning which was suitable for IOC learning as follows.

TABLE I. INDICATORS OF STUDENTS' COMMUNICATIVE SKILLS

\begin{tabular}{|c|c|l|l|}
\hline No & Aspect & \multicolumn{1}{|c|}{ Indication } & \multicolumn{1}{c|}{ Description } \\
\hline 1 & $\begin{array}{c}\text { Verbal } \\
\text { Communication }\end{array}$ & $\begin{array}{l}\text { Negotiating to achieve } \\
\text { a goal and agreement }\end{array}$ & $\begin{array}{l}\text { Actively expressing } \\
\text { ideas during } \\
\text { discussion }\end{array}$ \\
\hline 2 & $\begin{array}{c}\text { Listening } \\
\text { Communication }\end{array}$ & $\begin{array}{l}\text { Trying to listen and } \\
\text { understand }\end{array}$ & $\begin{array}{l}\text { Listening } \\
\text { enthusiastically }\end{array}$ \\
\hline
\end{tabular}

Cognitive aspect in this research prioritized learning outcome in the form of fact and concept. Researcher arranged indicators which would be raised regarding learning outcome of comprehension concept in life's changing and sustainability, the growth of nationalism and culture, education, economic and social culture of people in the time of colonization competence.

\section{METHOD}

This research was a Classroom Action Research (CAR). CAR is a research which is done by teachers collaboratively to improve the performance of teachers regarding learning process quality, and improving students' learning outcome of both academic and non-academic aspects by reflective action and cycle mode. CAR used was Kemmis and Mc Taggart model which is consist of four steps [9]. The four main activities from the steps on each cycle are planning the action, implementing the action, observing, and reflecting. This research used two cycles.
Instruments used in this research aimed to collect data about the learning process in class, students' learning motivation, and students' learning outcome on the social subject, Islamic kingdoms in Indonesia, using inside-outside circle learning model. Observation was used to gather students' communication skills data, questionnaire used to gather learning motivation data, and written test used to gather students improvement regarding learning outcome of comprehension concept in life's changing and sustainability, the growth of nationalism and culture, education, economic and social culture of people in the time of colonization competence.

According to [10] CAR data analysis go through five steps, which are data gathering, data reduction, data explanation, data analysis, and data interpretation, and compare data analysis results on each cycle (in the form of a matrix, table and description). To analyze data in this research, the researcher used quantitative descriptive analysis technique, i.e. observation data, questionnaire, and written test with scoring criteria. After calculating the percentage, they are interpreting into a qualitative sentence.

Subjects in this CAR are teachers and students of fifthgrade students from one Elementary school in Surabaya. The number of the students are 39 people consisting of male and female students in academic year 2016/2017.

\section{RESULTS AND DISCUSSION}

Cooperative Learning IOC type is a cooperative learning model with small and big circles where students exchange information at the same time with different partners briefly and orderly. Cooperative Learning IOC model presents in education world especially classroom learning to give new mood during the learning process. According to [1] cooperative learning model can be used to improve students' learning motivation. It was supported by a research conducted by [11], learning outcome improved when group collaboration improved. If students motivation when working on group improved, so did their learning outcome.

\section{TABLE II. COMPARISON OF STUDENTS MOTIVATION IN} CYCLE I AND CYCLE II

\begin{tabular}{|c|c|c|c|}
\hline Number & Criteria & Cycle I & Cycle II \\
\hline 1 & Very Less & 0 & 0 \\
\hline 2 & Less & 5 & 1 \\
\hline 3 & Good enough & 9 & 4 \\
\hline 4 & Good & 24 & 32 \\
\hline 5 & Very good & 1 & 2 \\
\hline \multicolumn{2}{|c}{$\%$} & $62 \%$ & $82 \%$ \\
\hline
\end{tabular}

Based on the learning activity using cooperative learning IOC model in cycle I and II, it can be seen that students' learning motivation improved. It was in line with Sharan's opinion, that students who learn using cooperative learning model will have high motivation as they are pushed and supported by classmates [12]. [1] revealed that cooperative learning can be used to improve students' learning motivation. 
Communication as a process of interpreting which is done by someone over information, attitude, someone's behavior, talks, and feeling. Communicative skills is the ability to communicate or have a good relationship with certain symbols. Research result from [13] explained that students can improve their ability to cooperate and communicate with their friend using Cooperative Learning IOC model.

TABLE III. COMPARISON OF STUDENTS COMMUNICATION IN CYCLE I AND CYCLE II

\begin{tabular}{|c|c|c|c|}
\hline Number & Criteria & Cycle I & Cycle II \\
\hline 1 & Veri good & 0 & 0 \\
\hline 2 & Good & 27 & 32 \\
\hline 3 & Good enough & 5 & 5 \\
\hline 4 & Less & 7 & 2 \\
\hline \multicolumn{2}{|c|}{$\%$} & $69 \%$ & $82 \%$ \\
\hline
\end{tabular}

It can be concluded that using IOC model to improve students' communicative skills was successful from cycle I to cycle II. It was supported by [1] who said that the advantage of Cooperative Learning IOC model is students have a lot of chances to process information and develop their communicative skills. One of cooperative learning IOC model aims is academic learning outcome, which helps students understand difficult concepts.

TABLE IV. COMPARISON OF STUDENT'S COGNITIVE ASPECT OF CYCLE I AND CYCLE II

\begin{tabular}{|c|c|c|c|}
\hline Number & Criteria & Cycle I & Cycle II \\
\hline 1 & Succes & 31 & 33 \\
\hline 2 & Not Succes & 8 & 6 \\
\hline \multicolumn{2}{|c|}{$\%$} & $79 \%$ & $85 \%$ \\
\hline
\end{tabular}

By using Cooperative Learning IOC model, students' cognitive aspects learning outcome showed improvement from cycle I to cycle II. The material was given unconventionally and the teacher emphasized more on to students' involvement so their attention and concentration will improve. Cooperative Learning IOC model application was proven can improve students' attention and concentration.

Bringing interesting learning environment can improve students' learning outcome. Cooperative learning IOC model is one of the cooperative learning models which is interesting to be applied. Furthermore, [12] said that creating interesting class environment can make students felt easier to understand the material. Cooperative Learning IOC model can improve interaction among students and between students and teacher, so students can improve their learning outcome. Students' learning outcome improvement can be seen in the following table.

TABLE V. STUDENTS’ LEARNING OUTCOME IMPROVEMENT

\begin{tabular}{|c|c|c|c|}
\hline No & Learning outcome aspect & Cycle I & Cycle II \\
\hline 1 & $\begin{array}{c}\text { Communicative skills } \\
\text { aspect }\end{array}$ & $69 \%$ & $82 \%$ \\
\hline 2 & Cognitive aspect & $79 \%$ & $85 \%$ \\
\hline \multicolumn{2}{|c|}{ Average } & $74 \%$ & $83,5 \%$ \\
\hline
\end{tabular}

\section{CONCLUSION}

Based on the results of data analysis and discussion of research results, this research concludes that: (1) the application of cooperative learning IOC model can improve the fifth-grade students' learning motivation. Students' good learning motivation improved from $62 \%$ in cycle I to $82 \%$ in cycle II. This research can be considered successful because students' motivation can achieve $>80 \%$; (2) the application of cooperative learning IOC model can improve the fifth-grade students' learning outcome. This research can be considered successful because students' learning outcome was $>80 \%$. In cycle I, students' learning outcome was $74 \%$ and improved to $83.5 \%$ in cycle II.

Based on results of the implementation of cooperative learning inside outside circle model the following are some related suggestions: (1) teachers pay more attention to the allotment of time with much material for discussion by students; (2) consider that students must stand while recording information obtained from friends; (3) facilitate the observer in giving score during observation, then each student is given the number of chest in the order of absence; (4) ideal conditions of classrooms maximum capacity is 28 learners, with spacious classrooms minimum ratio is $2 \times 2$ meters each student.

\section{REFERENCES}

[1] M. Huda, "Cooperatif Learning Metode, Teknik, Struktur dan Penerapan," Yogyakarta: Pustaka Jakarta, 2011.

2] T. Witteck, B. Most, G. Leerhoff, and I. Eilks, "Cooperative learning on the internet using the ball bearing method (Inside-OutsideCircle)," Science Education International, vol. 15, pp. 209-223, 2004.

[3] A. Supriyono, "Cooperatif learning," ed: Yogyakarta: Putaka Belajar, 2009.

[4] A. Shoimin, "model pembelajaran inovatif dalam kurikulum 2013," ed: Yogyakarta: Ar-Ruzz Media.

[5] F. Himam, "Interaksi dan motivasi belajar mengajar," Jakarta Rajawali Pers, 2004

[6] D. W. Johnson, R. T. Johnson, and K. Smith, "The state of cooperative learning in postsecondary and professional settings," Educational Psychology Review, vol. 19, pp. 15-29, 2007.

[7] H. Spencer-Oatey, Culturally Speaking Second Edition: Culture Communication and Politeness Theory: Bloomsbury Publishing, 2008.

[8] D. Padgett and D. Allen, "Communicating experiences: A narrative approach to creating service brand image," Journal of advertising, vol. 26 , pp. 49-62, 1997

[9] S. Kemmis, R. McTaggart, and R. Nixon, The action research planner: Doing critical participatory action research: Springer Science \& Business Media, 2013.

[10] S. Tampubolon, "Penelitian tindakan kelas sebagai pengembangan profesi pendidik dan keilmuan," Jakarta: Erlangga, 2014

[11] A. H. Mohammad-Davoudi and A. Parpouchi, "Relation between Team Motivation, Enjoyment, and Cooperation and Learning Results in Learning Area Based on Team-based Learning among Students of Tehran University of Medical Science," Procedia-Social and Behavioral Sciences, vol. 230, pp. 184-189, 2016.

[12] D. Isjoni, "Cooperative Learning efektifitas pembelajaran kelompok," Bandung: Alfabeta, 2013.

[13] M. Sudrajad and A. Wijaya, "The Effectiveness Of Inside-Outside Circle Method By Using Cue Card For Students'speaking Ability At Seventh Graders," JEES (Journal of English Educators Society), vol. 1,2016 . 